\title{
PERAN PERSEPSI TERHADAP KETERLIBATAN ORANG TUA DAN REGULASI EMOSI PADA ORIENTASI MASA DEPAN MAHASISWA UNIVERSITAS $X$
}

\section{The Role of Parents Involvement Perception and Emotional Regulation Towards Future Orientation of University X Students}

\author{
Fifi Juniarti $^{1)}$, Sri Tiatri ${ }^{2)}$, Sesilia Monika ${ }^{3)}$ \\ 1)Program Studi Psikologi Universitas Bunda Mulia \\ 2) 3)Fakultas Psikologi Universitas Tarumanagara, Jakarta
}

Diterima 22 Februari 2019

\begin{abstract}
The objective of this research is to figure out the strength of impact that parental involvement and emotion regulation brings toward future orientation. Future orientation is the image that a person have about his future, that represented and reported. The future orientation that became the focus of this research is the future orientation in career domain. The parental involvement mean the participation and concerns parents provide in involvement, autonomy support, and warmth. Then, in emotion regulation term, research focused on the expression suppression dan cognitive reappraisal emotion regulation methods. Sampling method that used is purposive sampling (total of sample 242 student of bachelor programmes in Universitas X). The method of data analysis using linear regression of double correlation. The data shows that future orientation $(Y)$ influenced by the parental involvement (independent variable -1 or X1)and emotion regulation (independent variable -2 or X2). The double correlation between X1 and $X 2$ was scored 0,291, with the determinant coefficient $(R 2)$ 0,085. It means the strength of influence from the two independent variable is $8,5 \%$, and the $91,5 \%$ left influenced by others variables. At anova test, $F$ test was bigger than $F$ table $(11.032>3.04)$, so that parental involvement $(X 1)$ and emotion regulation (X2) influence future orientation simultaneously. The research shows that both of parental involvement and emotion regulation contributes or bring impact to the changes of future orientation.
\end{abstract}

Keywords: future orientation, parental involvement, emotion regulation.

\begin{abstract}
ABSTRAK
Penelitian ini dilakukan untuk melihat seberapa besar peran keterlibatan orang tua dan regulasi emosi terhadap orientasi masa depan. Orientasi masa depan merupakan gambaran yang individu bentuk berkaitan dengan masa depan, yang secara sadar direpresentasikan dan dikemukakan oleh individu. Orientasi masa depan yang menjadi perhatian dalam penelitian ini adalah orientasi masa depan pada domain karir. Keterlibatan orang tua yang dimaksud adalah bentuk partisipasi dan perhatian yang diberikan orang tua dalam bentuk keterlibatan, dukungan otonomi dan kehangatan. Kemudian pada regulasi emosi, yang menjadi perhatian adalah metode regulasi expression suppression dan cognitive reappraisal. Teknik pengambilan sampel yang digunakan adalah purposive sampling dengan jumlah sampel 242 partisipan yang merupakan mahasiswa S1 Universitas Tarumanagara. Metode analisis data menggunakan regresi ganda. Data hasil penelitian menunjukkan bahwa orientasi masa depan (dependent variable atau $\mathrm{Y}$ ) dipengaruhi oleh keterlibatan orang tua (independent variable-1 atau X1) dan regulasi emosi (independent variable-2 atau X2). Korelasi ganda antara X1 dan X2 terhadap Y sebesar 0,291, koefisien determinasi (R2) sebesar 0,085. Artinya besar pengaruh kedua variabel tersebut adalah 8,5 \%, 91,5\% sisanya dipengaruhi oleh variabel-variabel lain. Pada uji anova, F hitung lebih besar dari F tabel $(11.032>3.04)$ sehingga secara bersama-sama keterlibatan orang tua $(\mathrm{X} 1)$ dan regulasi emosi $(\mathrm{X} 2)$ berpengaruh terhadap orientasi masa depan (Y). Hasil penelitian menunjukkan bahwa kedua variabel keterlibatan orang tua dan regulasi emosi memberikan kontribusi atau pengaruh terhadap perubahan pada orientasi masa depan.
\end{abstract}

Kata Kunci: orientasi masa depan, keterlibatan orang tua, regulasi emosi

*Korespondensi Penulis:

E-mail: fifi.june@gmail.com, srit@fpsi.untar.ac.id, sesiliamonika@gmail.com 


\section{PENDAHULUAN}

Remaja dengan aspirasi tinggi dalam pendidikannya berpengaruh langsung pada pencapaian pendidikan mereka (Romero, 2013). Remaja dengan pemikiran berorientasi masa depan menunjukkan hubungan dengan penurunan tingkat dropout dalam penyelesaian pendidikan SMA. Individu yang didorong oleh orientasi masa depan akan memiliki motivasi yang kuat untuk sukses. Individu juga akan terus meningkatkan keterampilan dan pengetahuannya yang dilihat penting untuk mencapai tujuannya di masa mendatang (Mazibuko \& Tlale, 2014). Dengan memiliki orientasi masa depan, maka seseorang akan memiliki dasar untuk menetapkan tujuan-tujuan, melakukan perencanaan, mengeksplorasi pilihanpilihan yang ada dan membuat komitmen (Seginer, 2003). Oleh karenanya, akan menuntun proses perkembangan individu.

Contoh bagaimana orientasi masa depan membentuk jalur pendidikan dan pilihan karir seseorang dalam dilihat dalam pengalaman BS, seorang mahasiswa bidang ekonomi manajemen berusia 21 tahun. Ia mengatakan bahwa sejak SMP dan SMA, ia mengevaluasi bidang-bidang ilmu yang mungkin menjadi pilihannya di masa depan. BS sudah menetapkan tujuannya yakni menekuni jurusan manajemen dan entrepreneur sebagai tujuan akhirnya setelah kuliah dan bekerja beberapa tahun. Sebelum membuat keputusan tersebut, BS menemukan ia sepertinya tidak mampu menekuni bidang kedokteran dan arsitektur, dan kemudian memilih manajemen sebagai bidang yang ia rasa cukup sesuai dengan minat dan latar belakang keluarganya (B. Susanto, komunikasi personal, 24 Februari 2015).

Namun, sebagian remaja justru tidak memiliki orientasi masa depan. Seorang kepala divisi pembinaan mahasiswa di sebuah Universitas Swasta di Jakarta mengatakan banyak mahasiswa yang tidak memiliki orientasi masa depan. Sebagian dari mereka mengalami masalah akademis, mulai dari rendahnya motivasi, malas menghadiri pertemuan tatap muka, kesulitan dalam beradaptasi terhadap pelajaran-pelajaran, dan akhirnya menyebabkan mereka semakin lama menyelesaikan tanggung jawab studi mereka dan semakin tertekan dan tidak menikmati masa-masa studi mereka. Mereka kurang memiliki gambaran mengenai apa yang menyebabkan mereka mengambil studi dan kemudian hanya menjalani studi tanpa dorongan motivasi, perencanaan, dan strategi (C. Tanu, komunikasi personal, 30 Januari 2015).

Orang tua dan keluarga berperan penting dalam membentuk orientasi masa depan pada remaja (Seginer, 2009). Remaja yang memandang orang tuanya sebagai orang tua yang mendukung dan mendorong menunjukkan optimisme yang lebih kuat terhadap masa depan dan membangun orientasi masa depan yang luas dan berbeda. Namun penelitian mengenai peran keterlibatan orang tua secara langsung terhadap orientasi masa depan, tidak sebanyak peran keterlibatan orang tua dalam meningkatkan prestasi akademis.

Sejumlah penelitian menunjukkan bahwa pengasuhan orang tua dengan karakteristik kehangatan yang tinggi, kontrol perilaku, dan pemberian otonomi secara positif memprediksi beragam dampak perkembangan yang diharapkan seperti tingginya tingkat self-esteem, performa akademik dan kepercayaan diri (Supple \& Small, 2006). Selain itu, dukungan orang tua juga berhubungan dengan Indeks Prestasi (IP) yang tinggi pada remaja. Keterlibatan orang tua juga ditemukan berpengaruh besar dalam membentuk nilai-nilai yang dimiliki individu (Pomerantz, Kim, \& Cheung, 2012).

Keterlibatan orang tua diyakini berhubungan dengan rangkaian peningkatan dalam prestasi di sekolah dari level pendidikan SD, SMP hingga SMA, termasuk menjadi indikator dari pencapaian dan perkembangan dari sifat-sifat siswa yang mendukung pencapaian, seperti selfefficacy dalam pembelajaran, persepsi tentang kontrol pribadi terhadap prestasi 
sekolah, serta pengetahuan dan keterampilan regulasi diri (Green \& Walker, 2007). Seiring berkembangnya anak memasuki usia yang lebih dewasa, bentuk keterlibatan yang dibutuhkan semakin berkurang dalam hal kehadiran, dan aspek yang penting adalah dukungan otonomi dan kehangatan (Rosenzweig, 2001; Edelman, 2013; Wartman \& Savage, 2008). Keterlibatan yang diharapkan anak yang lebih besar, cenderung pada kesempatan untuk berdiskusi dalam pengambilan keputusan.

Selain faktor keterlibatan orang tua, faktor dari dalam diri setiap individu memegang peranan yang penting. Individu memiliki kemampuan uniknya, temperamen dan kecenderungan-kecenderungannya yang semuanya berperan dalam membentuk ataupun mengubah perilaku mereka, baik cita-cita ataupun pencapaian mereka (Desforges, \& Abouchaar, 2003). Salah satu faktor yang berperan dalam diri seseorang adalah emosi. Emosi merupakan sumber motivasi yang kuat dalam sepanjang kehidupan manusia, memperngaruhi aspirasi, tindakan dan pemikiran seseorang (Pastey \& Vijayalaxmi, 2006). Emosi berkaitan dengan mood, temperamen, kepribadian dan motivasi (Punithavathi, 2013). Emosi juga seringkali mempengaruhi beberapa aspek dalam perilaku seseorang. Regulasi Emosi yang efektif memiliki peranan penting dalam pencapaian perkembangan yang menjadi salah satu prasyarat dari sejumlah tugas perkembangan lainnya. Individu yang mampu mengontrol emosi akan lebih mudah dalam menyesuaikan diri (Punithavathi, 2013).

Adapun masa yang masih cukup baik untuk pengkajian orientasi masa depan adalah ketika individu dihadapkan pada pilihan-pilihan dan perubahan transisisional. Ketika individu beranjak dari masa remaja ke masa dewasa, di mana transisi ini membuat mereka berhadapan dengan keputusan-keputusan penting, seperti pilihan karir dan minat yang semakin serius. Dalam penelitian ini, peneliti berfokus pada mahasiswa yang berada pada usia remaja dan dewasa awal. Hal ini dikarenakan orientasi masa depan yang diteliti berfokus pada pilihan karir masa depan yang belum begitu muncul pada jenjang pendidikan menengah.

Permasalahan dalam penelitian ini adalah bagaimana perkembangan orientasi masa depan individu yang menempuh pendidikan tinggi berkaitan dengan pilihan akademis dan karir mereka di masa depan. Kemudian, bagaimana pengaruh persepsi terhadap keterlibatan orang tua dan regulasi emosi dalam orientasi masa depan individu. Tujuan penelitian ini adalah untuk menemukan pengaruh persepsi terhadap keterlibatan orang tua dan regulasi emosi terhadap orientasi masa depan. Orientasi masa depan yang diteliti dalam penelitian ini berfokus pada orientasi masa depan terkait dengan domain karir. Penelitian ini dapat berkontribusi bagi aplikasi dalam psikologi pendidikan.

Manfaat bagi mahasiswa adalah pemahaman mengenai evaluasi dan perbaikan yang diperlukan untuk pengembangan orientasi masa depan mereka. Bagi orang tua dapat memahami dan menjalankan peranannya dalam perkembangan akademis anak dan juga memahami bentuk kontribusi yang perlu diberikan terhadap orientasi masa depan anak. Bagi para pendidik dan para psikolog pendidikan dapat memberikan intervensi yang lebih fokus dan berguna untuk mengembangkan orientasi masa depan anak dan pencapaian akademis anak. Orientasi masa depan adalah gambaran yang dibentuk oleh individu berkaitan dengan masa depan, yang secara sadar direpresentasikan dan dikemukakan oleh individu. Domain inti dari kehidupan masa mendatang yang umum digunakan adalah: pendidikan, karir dan keluarga (Seginer, 2003). Orientasi masa depan terdiri dari tiga komponen, yaitu aspek motivasional, aspek representasi kognitif, dan aspek perilaku (Seginer, 2009). Komponen motivasional berpengaruh secara langsung terhadap dua komponen lainnya, dan juga mempengaruhi komponen perilaku secara tidak langsung (Seginer, 2009)..

Keterlibatan orang tua terwujud dalam banyak bentuk, termasuk pengasuhan yang baik di rumah yakni di dalamnya mencakup: dukungan pengawasan terhadap 
keamanan dan kestabilan lingkungan, stimulasi intelektual, diskusi antara orang tua dan anak, contoh yang baik dalam nilainilai edukasi dan sosial yang membangun, dan aspirasi yang tinggi berkaitan dengan pencapaian personal dan kewarganegaraan yang baik. Kemudian keterlibatan berikutnya terkait dengan kontak terhadap sekolah untuk berbagi informasi, partisipasi dalam kegiatan sekolah, partisipasi dalam tugas sekolah, dan partisipasi dalam penguasaan sekolah (Desforges, \& Abouchaar, 2003).

Adapun aspek-aspek keterlibatan orang tua pada usia individu yang lebih dewasa, seperti pada individu yang memasukan jenjang pendidikan tinggi meliputi kombinasi dari dukungan autonomi (autonomy support), kehangatan dan dukungan emosional, harapan tinggi (high expectation) dan penyediaan sumber daya dan pengalaman belajar merupakan bagian dari keterlibatan orang tua (Rosenzweig, 2001). Keterlibatan orang tua yang demikian berhubungan positif terhadap student engagement and pencapaian akademis.

Dukungan otonomi memberikan dampak yang besar pada perkembangan seorang remaja. Contohnya saja, para mahasiswa di tingkat terakhir banyak bertanya kepada orang tua mereka meminta nasihat dan petunjuk berkaitan dengan perencanaan dan tujuan karir mereka (Edelman, 2013; Wartman \& Savage, 2008). Kemudian, aspek kehangatan dan dukungan emosional membantu individu untuk bisa berkoneksi dengan orang lain dan memiliki keyakinan diri yang lebih baik sehingga dapat beradaptasi terhadap tuntutan tugas perkembangan yang dihadapi (Rosenzweig, 2001).

Definisi regulasi emosi sesuai yang dikemukakan oleh Gross (Lewis, Jones, \& Barrett, 2004; Gross, 2011) adalah bagaimana individu mencoba mengatur emosi-emosi mana saja yang dimiliki, kapan dapat memilikinya dan bagaimana individu mengalami dan mengekspresikan emosi-emosi tersebut.

Berdasarkan model proses regulasi emosi yang dikembangkan oleh Gross (Lewis, Jones, \& Barrett, 2004; Gross,
2011), terdapat dua jenis strategi yang dikenal secara luas oleh para peneliti regulasi emosi cognitive reappraisal dan exspressive suppresion. Cognitive reappraisal melingkupi usaha untuk memikirkan tentang situasi yang ada sehingga dapat mengubah arti dari situasi yang ada dan dampak emosi yang ditimbulkan, sedangkan expressive suppression melingkupi usaha-usaha untuk mencegah atau mengurangi perilaku berisi ekspresi emosi yang sedang berlangsung. Jenis strategi regulasi dari konsep inilah yang akan menjadi fokus dalam penelitian ini.

\section{METODE PENELITIAN}

Metode penelitian yang digunakan adalah penelitian kuantitatif dengan desain penelitian studi korelasional dengan teknik convenience sampling. Partisipan yang terlibat dalam penelitian ini berjumlah total 280 orang mahasiswa S1 yang sedang menempuh studi semester 5 ke atas dan seterusnya. Mahasiswa terdiri dari berbagai program studi, antara lain: Fakultas Teknik, Fakultas Hukum, Fakultas Psikologi, Fakultas Kedokteran, Fakultas Teknik Informasi, dan Fakultas Ilmu Komunikasi. Penelitian dilakukan di Universitas X pada tahun 2015.

Variabel-variabel yang diukur dalam penelitian ini adalah orientasi masa depan, persepsi terhadap keterlibatan orang tua, dan regulasi emosi. Adapun alat ukur yang dipakai terdiri dari 3 tiga bagian, sebagai berikut.

$\begin{array}{lcc} & \text { 1. Kuesioner Orientasi Masa Depan } \\ \text { adalah kuesioner yang diadaptasi dari } \\ \text { Future } & \text { Orientation Questionnaires }\end{array}$ (Seginer, 2009). Kuesioner tersebut dibagi menjadi dua bagian, yaitu: Hopes and Fears Open Ended Questionnaire, Prospective Life Course, Career Domain Scales (skala bidang karir), termasuk di dalamnya bagian tentang My Future Hopes and Fears dengan pilihan domain yang sama yaitu karir.

2. Kuesioner persepsi terhadap keterlibatan orang tua merupakan kuesioner yang diadaptasi dari of Parents Scales atau POPS, The College Student Scale (Robbins, 
1994). Kuesioner ini merupakan kuesioner mengenai persepsi tentang orang tua yang dibuat khusus untuk anak yang berada di pendidikan tinggi. Keterlibatan orang tua yang diukur terbagi menjadi 3 tiga dimensi yaitu keterlibatan, dukungan otonomi, dan kehangatan.

3. Kuesioner regulasi emosi merupakan kuesioner yang diadaptasi dari Emotion Regulation Questionnaire atau ERQ (Gross \& John, 2003). Kuesioner mengukur dua strategi regulasi emosi yang berbeda: cognitive reappraisal dan expressive suppression.

Alat ukur awalnya melalui proses penerjemahan dan adaptasi, serta dilakukan proses back translation dibantu oleh Z dua orang penerjemah. Pengolahan data statistik dimulai dengan memilah partisipan dengan data yang tidak valid karena tidak lengkap (missing), uji reliabilitas, uji normalitas, uji korelasi dan regresi, uji beda orientasi masa depan berdasarkan usia, semester dan nilai IPK. Adapun jumlah data yang valid berjumlah 242 data. Selanjutnya, 242 data ini yang diolah secara statistik. Data penelitian terdistribusi normal, dan semua alat ukur memenuhi syarat reliabilitas (koefisien realibilitas >0,7).

\section{HASIL DAN PEMBAHASAN}

Uji regresi dilakukan untuk melihat pengaruh dari variabel bebas terhadap variabel terikat. Adapun dalam penelitian ini terdapat dua variabel bebas (independent variable) yaitu variabel keterlibatan orang tua (X1) dan variabel regulasi emosi (X2), sehingga uji regresi yang digunakan menggunakan uji regresi ganda. Adapun hipotesis yang diajukan adalah:

Ho: Tidak terdapat hubungan yang signifikan dari persepsi terhadap keterlibatan orang tua (X1) dan regulasi emosi (X2) terhadap orientasi masa depan (Y).

H1: Terdapat hubungan yang signifikan persepsi terhadap keterlibatan orang tua (X1) dan regulasi emosi (X2) terhadap orientasi masa depan $(\mathrm{Y})$.

Berdasarkan uji anova didapatkan nilai $\mathrm{F}$ hitung sebesar $=11.032$ dengan derajat $\mathrm{df} 1$ $($ derajat kebebasan pembilang $)=2$ dan df 2
$($ derajat kebebasan penyebut $)=239$ Pada kolom signifikansi didapat nilai 0.000 . untuk menguji hipotesis yang diajukan apakah diterima atau ditolak dengan melihat signifikansi. Adapun ketentuan penerimaan atau penolakan apabila signifikansi di bawah atau sama dengan 0,05 maka Ha diterima dan Ho ditolak.

Pengujian hipotesis dengan membandingkan dengan $\mathrm{F}$ tabel dengan df 1 (pembilang) $=2$ dan df 2 (penyebut) $=239$ didapat 3.04 untuk taraf $5 \%$. Maka F hitung lebih besar $(11.032>3.04)$ dari $\mathrm{F}$ tabel sehingga Ha diterima dan Ho ditolak. Nilai $F$ hitung lebih besar dari $F$ tabel atau signifikansi $<0.05$ maka secara bersamasama X1 yaitu persepsi terhadap keterlibatan orang tua dan X2 yaitu regulasi emosi berkorelasi secara signifikan dengan $Y$ yaitu orientasi masa depan.

Korelasi ganda X1 dan X2 terhadap Y sebesar 0,291. Koefisien determinasi (R2) sebesar 0,085 digunakan untuk mengetahui persentase sumbangan variabel independen terhadap variabel dependen. Hal ini berarti sumbangan dari variable persepsi terhadap keterlibatan orang tua (X1) dan regulasi emosi (X2) terhadap orientasi masa depan (Y) sebesar 8,5\%, sedangkan sisanya 91,5\% ditentukan dari sumbangan variabel lainnya yang tidak dianalsis dalam penelitian ini. Selanjutnya, disajikan analisis tambahan yang mendukung hasil penelitian ini yaitu uji korelasi persepsi terhadap keterlibatan orangtua antara ayah dan ibu, orientasi masa depan antara tipe, dan perbedaan orientasi ditinjau dari usia, semester, dan IPK.

\section{Uji Korelasi antara Keterlibatan Ibu dan Keterlibatan Ayah dengan Orientasi Masa Depan.}

Keterlibatan orang tua yang diukur terdiri dari keterlibatan Ibu dan keterlibatan Ayah. Dari hasil uji korelasi, ditemukan koefisien korelasi keterlibatan Ibu dan orientasi masa depan sebesar 0,252 dengan signifikansi 0,000 . Karena $0,000<0,01$, maka terdapat hubungan yang signifikan antara keterlibatan Ibu dengan orientasi masa depan. Sementara koefisien korelasi keterlibatan Ayah dengan orientasi masa depan sebesar 0,170, dengan nilai 
signifikansi sebesar $0,004(<0,01)$. Maka terdapat hubungan yang sangat signifikan antara keterlibatan Ayah dengan orientasi masa depan. Keterlibatan orang tua baik ibu dan ayah berhubungan dengan orientasi masa depan.

Uji Korelasi Antara Tipe Expressive Suppression dan Cognitive Reappraisal Dengan Orientasi Masa Depan. Regulasi emosi memiliki dua tipe yaitu expressive suppression dan cognitive reappraisal. Tipe regulasi cognitive reappraisal ditemukan merupakan teknik regulasi emosi yang lebih positif dan sehat bagi individu. Dari hasil uji korelasi, ditemukan koefisien korelasi expression suppression dan orientasi masa depan sebesar 0,064, dengan signifikansi 0,161. Karena 0,161>0,05, maka tidak ada hubungan antara expression suppression dengan orientasi masa depan. Sementara koefisien korelasi cognitive reappraisal terhadap orientasi masa depan sebesar 0,170 , dengan nilai signifikansi sebesar $0,004 \quad(<0,01)$. Sehingga, dapat disimpulkan bahwa regulasi emosi jenis cognitive reappraisal memiliki hubungan yang sangat signifikan dengan orientasi masa depan. Dengan demikian, regulasi emosi jenis cognitive reappraisal lah yang perlu dikembangkan untuk mendukung terbentuknya orientasi masa depan.

\section{Perbedaan Orientasi Masa Depan Berdasarkan Usia}

Dalam uji beda orientasi masa depan berdasarkan usia, partisipan dibedakan menjadi 2 kelompok. Kelompok yang pertama adalah kelompok usia remaja (usia 19-21 tahun), dan kelompok yang kedua adalah kelompok dewasa (usia 22-25 tahun). Dari hasil uji beda (t-test), nilai $\mathrm{p}$ yang didapat sebesar 0,892 . Karena $p>0,05$, maka kedua varian populasi sama. Tidak ada perbedaan orientasi masa depan berdasarkan usia. Sehingga, orientasi masa depan pada kelompok usia remaja (19-21) dan kelompok usia dewasa awal (22-25) dalam penelitian ini, memiliki orientasi masa depan yang sama.

\section{Perbedaan Orientasi Masa Depan Berdasarkan Semester}

Dalam uji beda orientasi masa depan berdasarkan semester, partisipan terdiri dari 8 kelompok (semester 5, 6, 7, 8, $9,10,11$, dan 13). Dari hasil uji beda orientasi masa depan berdasarkan semester, nilai $\mathrm{p}$ sebesar $0,548, \mathrm{p}>0,05$. Nilai $\mathrm{p}$ hitung >0,05. Maka, tidak ditemukan perbedaan orientasi masa depan berdasarkan semester (lihat Lampiran 19). Namun, jika dilihat dari dinamika grafik, orientasi masa depan yang ada pada semester 5 hingga 7, berada pada level sedang (antara 110 s.d. 172). Kemudian berada pada level tinggi di semester 8 $(187,50)$. Adapun semester 8 merupakan semester dimana mahasiswa akan menyelesaikan studi mereka jika tidak mengalami ketertinggalan mata kuliah. Kemudian setelah semester 8, orientasi masa depan semakin menurun hingga kembali lagi pada level sedang.

\section{Perbedaaan Orientasi Masa Depan Berdasarkan IPK}

Dalam hasil uji beda orientasi masa depan berdasarkan IPK, partisipan dibagi menjadi 4 kelompok (2.00 hingga 2.50, 2.51 hingga 3.00, 3.01 hingga 3.50, lebih dari 3.50). Nilai $\mathrm{p}$ hitung yang didapat adalah sebesar 0,656. Nilai $\mathrm{p}>0,05$, maka data penelitian ini menunjukkan bahwa tidak ditemukan perbedaan orientasi masa depan berdasarkan IPK (lihat lampiran 20). Namun, jika dilihat dari grafik, orientasi masa depan kelompok partisipan dengan IPK 2.00 hingga 2.51 dan kelompok IPK diatas 3.50 terlihat berada pada dua level yang berbeda. Kelompok partisipan dengan IPK 2.00-2.50 berada pada level orientasi masa depan sedang $(160,57)$, dan kelompok partisipan dengan IPK di atas 3.00 memiliki orientasi masa depan level tinggi (175.71). Meskipun memang pada kelompok partisipan dengan IPK 2.51-3.00 dan 3.013.50 , terlihat nilai orientasi masa depan meningkat pada IPK 2.51-3.00 (meningkat menjadi level tinggi: 172,14), tetapi kemudian menurun pada kelompok IPK 3.01-3.50 (level sedang: 167,65). Untuk mendapatkan pemahaman yang lebih baik, perbedaan ini dapat dikaji lebih lanjut lagi pada penelitian mendatang. 


\section{SIMPULAN DAN SARAN}

Berdasarkan hasil penelitian ini, ditemukan bahwa orientasi masa depan mendapat kontribusi dari persepsi terhadap keterlibatan orang tua dan regulasi emosi. Besar kontribusi pengaruh kedua variabel tersebut terhadap orientasi masa depan adalah $8,5 \%$, sedangkan $91,5 \%$ sisanya adalah kontribusi dari variabel-variabel lain. Secara bersama-sama persepsi keterlibatan orang tua dan regulasi emosi berkorelasi terhadap orientasi masa depan. Hasil pengujian statistik yang dilakukan menunjukkan bahwa kedua variabel persepsi keterlibatan orang tua dan regulasi emosi memberikan kontribusi atau berpengaruh terhadap perubahan pada variabel orientasi masa depan, sehingga, jika diberikan perhatian lebih atau ataupun intervensi pada keterlibatan orang tua dan regulasi emosi, maka hal ini akan mendukung orientasi masa depan subjek penelitian.

Kemudian, lebih spesifik lagi, uji korelasi yang dilakukan mengkaji hubungan masing-masing variabel keterlibatan orang tua dan variabel regulasi emosi terhadap orientasi masa depan. Ditemukan bahwa terdapat hubungan yang sangat signifikan antara keterlibatan orang tua dengan orientasi masa depan, sedangkan terdapat hubungan yang signifikan antara regulasi emosi dengan orientasi masa depan. Hal ini menunjukkan bahwa pengaruh keterlibatan orang tua dalam orientasi masa depan sangatlah kuat, sehingga hal ini perlu menjadi salah satu aspek yang menjadi perhatian dalam pendidikan individu. Apabila keterlibatan orang tua didukung dengan regulasi emosi yang baik pada individu, maka tentu akan semakin membentuk orientasi masa depan yang baik pula.

Saran teoretis untuk bidang ilmu psikologi pendidikan yaitu memperkaya kajian penelitian-penelitian tentang orientasi masa depan pada mahasiswa dengan memperhatikan metode pemilihan sampel dan karakteristik subyek, seperti skala yang lebih besar dari segi jumlah dan heterogenitas partisipan. Selain itu, penggolongan karakteristik subyek yang lebih spesifik dengan kondisi-kondisi yang mungkin memberikan kontribusi dalam perkembangan individu seperti kondisi subyek dengan orang tua tunggal dapat juga dipertimbangkan.

Saran praktis bagi pihak orang tua agar dapat lebih terlibat dalam kehidupan anak, terutama dalam menjadi teman diskusi terkait dengan pilihan-pilihan yang anak akan ambil terutama keputusankeputusan penting seperti studi dan karir pada anak yg berusia lebih dewasa. Pengambilan keputusan hendaknya tetap ada dalam kontrol anak tapi pendampingan. Bagi mahasiswa sendiri dapat mengembangkan orientasi masa depan dengan mengeksplorasi sebanyakbanyaknya minat dan pilihan yang ada. Dengan eskplorasi, maka informasi dan pemahaman yang diperoleh akan menjadi pertimbangan yang berguna bagi orientasi masa depan. Selain itu, penting untuk dapat mengembangkan kemampuan regulasi emosi yang lebih sehat, agar mendukung orientasi masa depan yang lebih baik. Maka, lebih baik untuk mengubah cara berpikir dan konten yang dipikirkan daripada berusaha menekan perasaan untuk tidak diekspresikan.

Bagi Pendidik, peran serta aktif dapat dilakukan dengan menstimulasi mahasiswa untuk mengembangkan orientasi masa depan dengan memberikan informasiinformasi yang berguna. Kemudian pendidik juga dapat berbagai pertimbanganpertimbangan yang perlu diperhatikan dalam memilih opsi-opsi yang ada.

\section{DAFTAR PUSTAKA}

Aldao, A., Nolen-Hoeksema, S., \& Schweizer, S. (2010). Emotionregulation strategies across psychopathology: A meta-analytic review. Clinical psychology review, 30(2), 217-237.

Beal, S.J. (2011). The development of future orientation: underpinnnings and related construct. University of Nebraska: Department of Psychology.

Campbell-Sills, L., \& Barlow, D. H. (2007). Incorporating emotion 
regulation into conceptualizations and treatments of anxiety and mood disorders.

Cheung, C. S. S., \& Pomerantz, E. M. (2015). Value development underlies the benefits of parents' involvement in children's learning: A longitudinal investigation in the United States and China. Journal of educational psychology, 107(1), 309.

Cole, P. M., Martin, S. E., \& Dennis, T. A. (2004). Emotion regulation as a scientific construct: Methodological challenges and directions for child development research. Child development, 317-333.

Czaja, J., Rief, W., \& Hilbert, A. (2009). Emotion regulation and binge eating in children. International Journal of Eating Disorders, 42(4), 356-362.

Davis, E. L., \& Levine, L. J. (2013). Emotion regulation strategies that promote learning: Reappraisal enhances children's memory for educational information. Child development, 84(1), 361-374.

Desforges, C. \& Abouchaar, A. (2003). The impact of parental involvement, parental support and family education on pupil achievements and adjustment: a literature review. Nottingham, UK: Departement for Education and Skills Publications.

Desimone, L. (1999). Linking parent involvement with student achievement: Do race and income matter?. The Journal of Educational Research, 93(1), 11-30.

De Volder, M. L. \& Lens, W. (1982). Academic achievement and future time perspective as a cognitivemotivational concept. Journal of Personality and Social Psychology, 42(3), 566.

Diamond, L.M. \& Aspinwall, L.G. (2003). Emotional regulation across the life Span: an integrative perspective emphasizing Self-Regulation, Positive affect, and Dyadic Processes. Motivation and Emotion, 27 (2), June 2003.

Edelman, L. (2013). The effects of parental involvement on the college student transition: A qualitative study (Master's thesis). University of Nebraska-Lincoln, Lincoln, NE.

Eisenberg, N. (2000). Emotion, regulation, and moral development. Annual review of psychology, 51(1), 665697.

Fan, X., \& Chen, M. (2001). Parental involvement and students' academic achievement: A metaanalysis. Educational psychology review, 13(1), 1-22

Green, C. L., Walker, J. M., HooverDempsey, K. V., \& Sandler, H. M. (2007). Parents' motivations for involvement in children's education: An empirical test of a theoretical model of parental involvement. Journal of educational psychology, 99(3), 532.

Gross, J. J., \& John, O. P. (2003). Individual differences in two emotion regulation processes: implications for affect, relationships, and wellbeing.Journal of personality and social psychology, 85(2), 348.

Gross, J. J., \& Barrett, L. F. (2011). Emotion generation and emotion regulation: One or two depends on your point of view. Emotion review, 3(1), 8-16.

Halperin, E., Sharvit, K., \& Gross, J. J. (2011). Emotion and emotion regulation in intergroup conflict: An appraisal-based framework. Intergroup conflicts and their resolution: A social psychological perspective, 83-103.

Hill, Nancy E., \& Tyson, D.F. (2009). Parental involvement in middle school: a meta-analytic assessment of the strategies that promote achievement. Developmental psychology, 45(3). 740-763.

Holopainen, L., \& Sulinto, S. (2005). Adolescents' health behaviour and future orientation. University of Jyväskylä.

Jeynes, W. H. (2005). A meta-analysis of the relation of parental involvement to urban elementary school student academic achievement.Urban education, 40(3), 237-269. 
Jeynes, W. H. (2007). The relationship between parental involvement and urban secondary school student academic achievement a metaanalysis.Urban education, 42(1), 82110.

John, O. P., \& Gross, J. J. (2004). Healthy and unhealthy emotion regulation: Personality processes, individual differences, and life span development. Journal of personality, 72(6), 1301-1334.

Kintrea, K., St Clair, R., \& Houston, M. (2011). The influence of parents, places and poverty on educational attitudes and aspirations. Joseph Rowntree Foundation.

Kumar, S., Sharma, M., \& Singh, R. (2014). Personality Factors as Correlates of Emotional Maturity among Adolescents. Journal of the Indian Academy of Applied Psychology, 40(2), 221

Lopes, P. N., Salovey, P., Côté, S., Beers, M., \& Petty, R. E. (2005). Emotion regulation abilities and the quality of social interaction. Emotion, 5(1), 113.

Mazibuko, M.E., \& Tlale, L.D.N. (2014). Adolescents' positive future orientation as a remedy for substance abuse: an ecosystemic view. Mediterranean Journal of Social Science, 5 (2), 69-78

Mester, D. (2013). Research of the background factors influencing college student's future orientation. Theses of Doctoral Dissertation. University of Debrecen

Morris, A. S., Silk, J. S., Morris, M. D., Steinberg, L., Aucoin, K. J., \& Keyes, A. W. (2011). The influence of mother-child emotion regulation strategies on children's expression of anger and sadness. Developmental psychology, 47(1), 213.

Nurmi, J. E. (2002). An introduction: Thinking about, preparing for and negotiating the future. Adolescents' future-orientation. Oxford: Peter Lang.

Ochsner, K. N., \& Gross, J. J. (2008). Cognitive emotion regulation insights from social cognitive and affective neuroscience. Current Directions in Psychological Science, 17(2), 153-158

Pastey, G. S., \& Aminbhavi, V. A. (2006). Impact of emotional maturity on stress and self confidence of adolescents. Journal of the Indian Academy of Applied Psychology, 32(1), 66-70.

Pomerantz, E. M., Kim, E. M., \& Cheung, C. (2012). Parents' involvement in children learning. Dalam Harris, K. R., Graham, S., \& Urdan, T. (Editor), individual difference and Culturral and Contextual Factors. American Psychological Association

Punithavathi, S. (2013). Emotional Maturity and Decision Making Styles Among Arts And Science And Engineering College Women STUDENTS. Asia Pacific Journal of Marketing \& Management Review, 2 (4), 46-49.

Richards, J. M., \& Gross, J. J. (2000). Emotion regulation and memory: the cognitive costs of keeping one's cool. Journal of personality and social psychology, 79(3), 410.

Robbins, R. J. (1994). An assessment of perceptions of parental autonomy support and control: Child and parent correlates. Unpublished Doctoral Dissertation, Department of Psychology, University of Rochester, 1994.

Romero, A. (2013). Educational future orientation of middle school latino students. Counseling and Psychological Services Dissertation. Georgia State University.

Rosenzweig, C. (2001). A Meta-Analysis of Parenting and School Success: The Role of Parents in Promoting Students' Academic Performance.

Seginer, R. (2003). Adolescent Future Orientation: An Integrated Cultural and Ecological Perspective. Online Readings in Psychology and Culture, 6(1), 5. http://dx.doi.org/10.9707/23070919.1056. 
Seginer, R. (2009). Future orientation:

Developmental and ecological perspectives. New York: Springer.

Sénéchal, M., \& LeFevre, J. A. (2002). Parental involvement in the development of children's reading skill: A five-year longitudinal study. Child development, 73(2), 445-460.

Sheppes, G., \& Gross, J. (2012). Emotion regulation effectiveness: What works when. Dalam H. A. Tennen dan J. M. Suls (Eds.), Handbook of Psychology, Volume Five: Personality and Social Psychology. New York, NY: Wiley

Supple, A. J., \& Small, S. A. (2006). The influence of parental support, knowledge, and authoritative parenting on Hmong and European American adolescent development. Journal of family Issues, 27(9), 1214-1232.

Steinberg, L., Graham, S., O'Brien, L., Woolard, J., Cauffman, E., \& Banich, M. (2009). Age differences in future orientation and delay discounting. Child development, 80(1), 28-44.

Tamir, M. (2011). The maturing field of emotion regulation. Emotion Review,3(1), 3-7.

Tottenham, N., Hare, T. A., \& Casey, B. J. (2011). Behavioral assessment of emotion discrimination, emotion regulation, and cognitive control in childhood, adolescence, and adulthood. Frontiers in psychology, 2.

Trempała, J. (2002). Adolescents' futureorientation: theory and research (Vol. 691). Peter Lang Publishing.

Wartman, K. L., \& Savage, M. (2008). Parental involvement in higher education: Understanding the relationship among students, parents, and the institution. Jossey-Bass. 